\title{
Capsizing in canyons
}

\section{Susannah Porter, Carol Dehler and colleagues hiked miles in burning heat and braved unforgiving river rapids to sample rocks in the Grand Canyon.}

What was the objective of the work? We wanted to study life and the environment in the early part of the Neoproterozoic era, 1,000 to 542 million years ago, just before the low-latitude ('Snowball Earth') glaciations around 726-635 million years ago. Relatively little is known about life and how it responded to the major climatic and geochemical perturbations that took place during this period. The Chuar Group - a lithified sequence of Neoproterozoic sediments laid down in a shallow ocean in the Grand Canyon area, long before the Grand Canyon existed - contains abundant and incredibly well-preserved fossil assemblages, and thus provided an excellent opportunity to examine this interval in more detail.

\section{Why did you choose this location?} This is the only location where the Chuar Group is exposed, so there was no choice in the matter!

\section{What sorts of samples were} you after?

We wanted fossils preserved in a detailed stratigraphic and sedimentologic context, so that we could control for palaeoenvironmental influences on fossil patterns. Unfortunately, the majority of the fossils are microscopic, and most of the time we didn't know whether we had collected any until we got back to the lab and processed our samples. Nonetheless, we knew from previous studies to target black, green and grey shale, and black chert. In addition, we discovered incredibly abundant protozoan fossils in carbonate nodules that formed in upper Chuar Group shale.

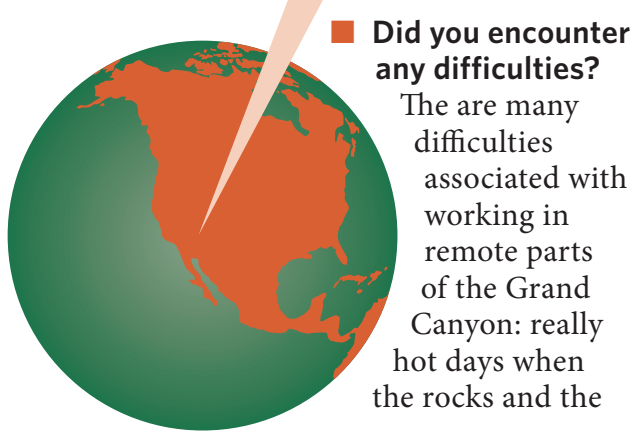

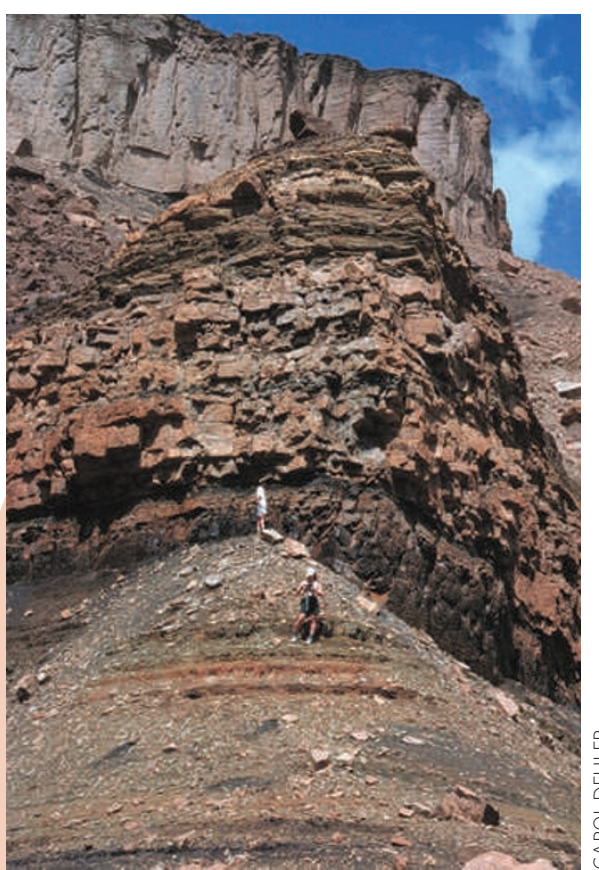

Any low points?

When our 22-foot motorized raft capsized, we lost the entire kitchen to the rapid, and the river guide lost his glasses. Our two field assistants swam the rapid - called Lava Falls - and the river guides pulled them out at the other end. Luckily, our samples remained dry.

\section{What were the highlights of the expedition?}

Working outdoors provided its own rewards. After a day out in the field we would sit back and enjoy a gin and tonic around the campfire. And as we fell asleep we could look up at the stars. A particular highlight of the trip was when we rode through the rapids and descended into 'Powell's bowels' - where the oldest rocks in the Grand Canyon frame the river passage. These rocks formed deep in the Earth approximately 1.8 billion years ago, and are very different in appearance from the overlying rocks.

Susannah Porter and Shari Kelly sampling the Chuar Group in the Grand Canyon.

geologists get bleached by the sun; rare rainy days when it becomes impossible to take notes because of wet paper; scorpions; mountain lion tracks; and unnerving cliff passes. But perhaps most scary was one of our trips to the field site where the Chuar Group rocks are exposed. Usually we would travel by boat (or once by helicopter), but one time a few of us decided to go by foot on an unmaintained 'route' along the North Rim of the Grand Canyon. This is a 17-mile hike, and we miscalculated just how much water we would need. By the time we neared the end of the trail, we were all suffering from serious dehydration. When we found a spring, we plopped down by the water, exhausted, only to find that there were poisonous plants growing in it.

\section{Did you have encounters with} dangerous animals?

The greatest danger to us was the sun, although we occasionally startled a rattlesnake or a scorpion.
Was it straightforward to get the samples back to the lab?

On boat trips, we simply loaded the rocks onto the boats, and motored the $\sim 150$ miles downstream to camp (which took several days), to the boat ramp, where we would get a shuttle back to our cars. On the helicopter trip we had to restrict our sampling owing to weight limits, which was challenging. And on our epic 17-mile backpack trip, we lugged the samples down to the Colorado River (another five miles, round trip), and stashed them on a beach for a river guide to pick up later.

Did the trip give you any ideas for future research projects?

We are now keen to look for evidence of the biotic transition in other rocks of the same age, and to continue exploring the Chuar Group in search of more clues about the early Earth system.

This is the Backstory to the work by Robin Nagy and colleagues, published on page 415 of this issue. 